\title{
Peripheral Glucose Metabolism in Control Subjects and Diabetic Patients During Glucose, Glucose-Insulin and Insulin Sensitivity Tests
}

\author{
By \\ W. J. H. Butterfield and Margaret J. Whichelow \\ From the Department of Medicine, Guy's Hospital Medical School, London
}

Received March 24, 1965

Summary. Glucose uptake was measured in the deep forearm tissues of four control subjects, and four adultonset and four juvenile-onset diabetics, before and during a glucose tolerance, a glucose-insulin tolerance and a peripheral insulin sensitivity test.

1. The controls showed an increase of glucose uptake above the fasting level in all three tests, more conspicuous in the lean subjects.

2 . In the adult-onset type diabetics there was a small increase in glucose uptake after glucose alone, but this was restored to normal by the injection of insulin.

3. No increase in glucose uptake was found in the juvenile-type diabetics after glucose, and very little when insulin was administered. Despite this insulin insensitivity of the peripheral tissues in these diabetics, there is evidence of some insulin sensitive site elsewhere, and the reasons for believing that this is the liver and splanchnic area are discussed.

Résumé. La captation du glucose a été mesurée dans les tissus profonds de l'avant-bras chez quatre sujets témoins, chez quatre sujets devenus diabétiques à l'âge adulte, ainsi que chez quatre sujets atteints de diabète juvénile, avant et pendant une épreuve de tolérance au glucose, une épreuve de tolérance à l'insuline-glucose ainsi qu'au cours d'un test périphérique de sensibilité à l'insuline.

1. Les témoins ont présenté une augmentation de la captation du glucose au dessus du niveau existant à l'état de jeûne dans les trois tests, bien que cette augmentation soit plus évidente chez les sujets maigres.

2. Chez les sujets devenus diabétiques à l'âge adulte, il a été constaté une faible augmentation de la captation du glucose après glucose seul, mais le retour à la normale était produit par l'injection d'insuline.
3. Aucune augmentation de la captation du glucose a été trouvée chez les sujets atteints de diabète juvénile après administration de glucose; cette augmentation était très faible lorsque de l'insuline était administrée. En dépit de cette insensibilité à l'insuline des tissus périphériques chez ces diabétiques, il y avait des manifestations d'un certain degré de sensibilité à l'insuline en d'autres endroits de l'organisme; les raisons qui inclinent à penser que le foie et les aires splanchniques sont impliqués sont discutées.

Zusammenfassung. Bei vier Kontrollpersonen und je vier Diabetikern mit Manifestation des Diabetes im Erwachsenenalter und in der Jugend wurde die Glukoseaufnahme in den tiefen Geweben des Unterarms, vor und während eines Glukosetoleranztestes, eines GlukoseInsulin-Toleranztestes und eines peripheren Insulinempfindlichkeitstestes gemessen.

1. Die Kontrollpersonen zeigten bei allen drei Testen ein Ansteigen der GIukoseaufnahme über den Nüchternwert, das bei den mageren Patienten deutlicher war.

2. Bei den Diabetikern mit Beginn der Erkrankung im Erwachsenenalter stieg die Glukoseaufnahme nach Glukose allein gering an, doch sank sie nach Insulininjektion wieder auf den Normalwert ab.

3. Bei den Diabetikern mit Manifestation der Erkrankung in der Jugend wurde nach Glukose kein und nach Insulin nur ein geringes Ansteigen der Glukoseaufnahme gefunden. Trotz dieser Insulinunempfindlichkeit der peripheren Gewebe ist bei diesen Diabetikern augenscheinlich an anderer Stelle eine gewisse Insulinempfindlichkeit vorhanden. Die Gründe für die Annahme, $\mathrm{da} B$ diese Stelle die Leber und das Splanchnicusgebiet ist, werden erörtert.
The idea of testing glucose metabolism by following the body's ability to dispose of an oral load of glucose was introduced by JACOBSEN in 1917. Since then, the oral glucose tolerance test has passed into standard practice and a very large number of patients has been subjected to this simple procedure: levels have been designated for the upper limits of normality for the blood sugar fasting and at 1,2 and $21 / 2$ hours after $50 \mathrm{~g}$ glucose and values in excess of these limits have been taken as diagnostic of diabetes mellitus.

There have been elaborations of the test. To compensate for variations in body weight, some investigators give a glucose dose standardised to $0.7 \mathrm{~g}$ per $\mathrm{kg}$ body weight, others on a surface area basis, while in the U.S.A., $100 \mathrm{~g}$ are usually given as one dose and in Switzerland and Germany two loading doses of $50 \mathrm{~g}$ glucose are used. A more important innovation has been to inject the glucose intravenously, to overcome differences in gastro-intestinal absorption. However this test is not in general use, and there is still lack of agreement among users about inter- pretation, some preferring to follow the fall of blood sugar in absolute values, others plotting all results as the increments over fasting levels. These points have recently been well reviewed by LONDBAEK (1962) who recommends the use of the intravenous test for the diagnosis of diabetes and latent diabetes and to assess antidiabetic therapy. Nevertheless, it will probably be some time before all diabetics are diagnosed in this way, especially as the quick intravenous injection of $25 \mathrm{~g}$ glucose requires a wide bore needle, causes pain if there is extravasation and may lead to local thrombosis. Consequently, the oral load test with which we are here concerned is still in widespread use today.

This test has also been modified to assess the patient's sensitivity to insulin. By giving the standard oral dose on one day, and the same load on another day but with insulin, 0.1 unit per $\mathrm{kg}$ body weight intravenously at the start of the test and comparing the two curves, Hrysworte and KerR (1939) showed that young lean diabetics were more sensitive to insulin than cases with diabetes due to Coshing's disease and 
this has been confirmed by many other investigators. They also concluded that elderly, plump cases were more often insulin insensitive, but this view has not been substantiated.

Where does the sugar go in these oral glucose tests? In considering this question workers often neglect the fact that the body is made up of various organs and tissues, and overlook the possibility that glucose may go to one tissue in one case and a different one in another, and yet give similar systemic curves. Despite the very wide clinical use of glucose tolerance tests of one sort or another, we know of no reliable information based on measurement in man about disposal of the glucose load by the various tissues of the body. We have therefore undertaken the present investigations using the technique previously described (BDTTERBIELD and HoLLING 1959), to follow the glucose metabolism of the deep muscular compartment of the forearm tissues. Healthy subjects with normal glucose metabolism were studied for comparison with young, severe, ketotic insulindependent diabetics, taken as representative of growth-onset diabetes, and mild non-ketotic cases from which we attempt to deduce the role of different organs in glucose metabolism.

\section{Methods}

Clinical Material. Table 1 gives the age, sex, diagnosis, details of anti-diabetic therapy, tendency to ketosis and mean fasting arterial glucose level of the four non-diabetic subjects, four elderly-type and four juvenile type diabetics who were studied. All investigations were carried out in the morning after an overnight fast, with the subject lying comfortable and warm in bed in the ward. With the insulin dependent diabetics, soluble insulin only was administered for two days preceding any test. All anti-diabetic drugs soluble insulin or oral anti-diabetics - were withdrawn sixteen hours before the test.

Experimental. The forearm preparation described in detail previously (BUTTERFIELd and Holling 1959) was used in these studies. Briefly, fine polythene catheters were inserted, under local anaesthesia and through thin walled needles, into the brachial artery and into a suitable antecubital vein draining the deep

Table 1. Clinical details of subjects studied

\begin{tabular}{|c|c|c|c|c|c|c|c|c|}
\hline Subject & Sex & Age & $\begin{array}{c}\text { Duration } \\
\text { of Diabetes }\end{array}$ & $\begin{array}{l}\text { Tendenoy } \\
\text { to Ketosis }\end{array}$ & $\begin{array}{l}\text { Range of } \\
\text { Dailly Insu- } \\
\text { lin Dose }\end{array}$ & $\begin{array}{l}\text { Other Anti- } \\
\text { diabetic therapy }\end{array}$ & $\begin{array}{c}\text { Fasting } \\
\text { Blood } \\
\text { Sugar. }\end{array}$ & $\begin{array}{l}\text { Body } \\
\text { Build }\end{array}$ \\
\hline \multicolumn{9}{|l|}{ Control } \\
\hline $\begin{array}{l}\text { P.H.W. } \\
\text { J.B. } \\
\text { F.N. } \\
\text { I.K.F. }\end{array}$ & $\begin{array}{l}\mathrm{M} \\
\mathrm{M} \\
\mathrm{M} \\
\mathrm{M}\end{array}$ & $\begin{array}{l}37 \\
30 \\
24 \\
32\end{array}$ & $\begin{array}{l}- \\
- \\
-\end{array}$ & $\begin{array}{l}- \\
- \\
-\end{array}$ & $\begin{array}{l}- \\
- \\
-\end{array}$ & $\begin{array}{l}- \\
\overline{-} \\
-\end{array}$ & $\begin{array}{l}71 \\
69 \\
77 \\
72\end{array}$ & $\begin{array}{l}\text { Plump } \\
\text { Lean } \\
\text { Plump } \\
\text { Lean }\end{array}$ \\
\hline \multicolumn{9}{|c|}{ Elderly Type Diabetics } \\
\hline E.S. & $\mathrm{F}$ & 68 & 8 yrs. & 0 & nil & $\begin{array}{l}\text { Chlorprop- } \\
\text { amide. }\end{array}$ & 183 & Obese \\
\hline B.H. & $M$ & 45 & 3 months & 0 & nil & Tolbutanaide & 131 & Lean \\
\hline Е.H. & $\mathrm{M}$ & 69 & $40 \mathrm{yrs}$ & + & $\begin{array}{l}0-44 \\
\text { units }\end{array}$ & Phenformin & 134 & Lean \\
\hline B. B. & $\mathrm{F}$ & 54 & 3 months & 0 & nil & Diet & 183 & Plump. \\
\hline \multicolumn{9}{|c|}{ Juvenile Type Diabetics } \\
\hline J.T. & $\mathrm{F}$ & 18 & 7 yrs. & +++ & $\begin{array}{l}36-100 \\
\text { units }\end{array}$ & nil & 388 & Plump \\
\hline H.W. & M & 22 & 6 yrs. & +++ & $\begin{array}{l}60-120 \\
\text { units }\end{array}$ & nil & 369 & Plump \\
\hline M. C. & $\mathrm{F}$ & 30 & 12 yrs. & $++t$ & $\begin{array}{l}50-110 \\
\text { units }\end{array}$ & nil & 293 & Average \\
\hline D.S. & M & 37 & $12 \mathrm{yrs}$ & +++ & $\begin{array}{l}60-110 \\
\text { units }\end{array}$ & nil & 384 & Lean \\
\hline
\end{tabular}

controlled by oral antidiabetic therapy representing adult-onset diabetes. Three separate tests were carried out on each subject, an oral glucose tolerance test, an oral glucose-insulin tolerance test and a peripheral insulin sensitivity test.

The results reveal interesting differences between the peripheral glucose disposal in thin and plump normal subjects and elderly and juvenile diabetics, muscular compartment of the forearm. These catheters facilitated repeated blood sampling over a period of up to 3 hours, during which time they were kept patent by a slow infusion (up to $1 / 2 \mathrm{ml} / \mathrm{min}$ ) of saline containing heparin (2 units $/ \mathrm{ml}$ ). Blood flow was estimated four times during collections with a venous occlusion plethysmograph. The hand circulation was occluded by inflating a cuff at the wrist to at least $200 \mathrm{~mm} \mathrm{Hg}$, 
for one minute before and during all sampling procedures.

Test. In all tests three or four determinations of glucose uptake were made during an initial fasting period of $20-25$ minutes. In the glucose tolerance test the subjects were then given $50 \mathrm{~g}$ glucose in $120 \mathrm{ml}$ liquid orally, and arterial and venous samples were taken with concomitant blood flow measurements for estimates of glucose uptake $15,30,45,60,75,90$, 120 and 150 minutes later. For the glucose-insulin tolerance test the same carbohydrate load was administered together with 7 units of glucagon-free insulin intravenously and samples taken after 5, 10, $15,30,45$ and 60 minutes. In the third test an injection of 0.1 unit glucagon-free insulin in $2 \mathrm{ml}$ saline (or on two occasions 1.0 unit) was given through the catheter into the brachial artery over two minutes, the wrist cuff being inflated for one minute before starting and throughout the injection. Samples were then collected $5,10,15,20,30$ and 40 minutes later.

Blood glucose levels were measured in duplicate on $0,5 \mathrm{ml}$ blood samples by the glucose oxidase method of HUGGETT and NIXoN (1957) using a minor modification involving weighing the blood rather than pipetting. On separate occasions blood pyruvate levels were measured in the hepatic vein as well as in the brachial artery and antecubital vein during glucoseinsulin tolerance tests by our colleague, Dr. I. KeISEY FRY, using the chromatographic method of McArdeE (1957).

Calculations. From the arterio-venous glucose differences $(\mathrm{A}-\mathrm{V})$ and the blood flow (B.F.), the tissue glucose uptake (T.G.U.) was estimated: $(\mathrm{A}-\mathrm{V}) \times \mathrm{B} . \mathrm{F} .=\mathrm{T} . \mathrm{G} . \mathrm{U}$. The blood glucose level was expressed as $\mathrm{mg}$ glucose $/ 100 \mathrm{ml}$ blood, the blood flow as $\mathrm{ml} \mathrm{blood} / 100 \mathrm{ml}$ forearm/minute, and the tissue glucose uptake as $\mathrm{mg}$ glucose $/ 100 \mathrm{ml}$ forearm $/$ minute.

However, the uptake of glucose by the tissues is not necessarily the same as the cell glucose uptake. If it is assumed that the level of glucose in the venous blood approaches equilibrium with that in the extracellular fluid, estimates can be made of cell glucose uptake by correcting the tissue (i.e. extracellular fluid plus cells) uptake for the glucose which shifts into or out of the extracellular fluid, as described previously (Bdtterfield, Garratt and Whichelow 1963). Cell glucose uptake was expressed in $\mathrm{mg}$ glucose per $100 \mathrm{ml}$ forearm per minute.

ZIERLER (1961) has set out some theoretical considerations and calculations about the reliability of applying the Fick Principle to the conditions in experiments such as these involving changing arterial glucose levels, and has raised the question as to whether simultaneous arterial and venous sampling over a period of one minute is adequate to allow for the mean glucose transit time. We have presented elsewhere some pertinent experimental evidence based on intra-arterial injections of glucose (BUTTERFIELD and HoLLIYG 1959) and intravenous glucose injections,
(Butterfieud and WhrCHELOW 1964) showing that under the conditions of our experiments the mean glucose transit times are probably shorter than Zierler suggests. Thus, on an empirical rather than a theoretical basis, we are confident that our calculations cannot be too greatly in error. Certainly such errors could not account for the very pronounced differences observed between the various groups, which became the main feature of the study.

\section{Results}

Details of the results obtained for the glucose, glucose-insulin and intra-arterial insulin tests are presented in Tables $2-4$.

Analysis. Negative arterio-venous differences, especially amongst diabetics, have been recorded before (BUTTERFIELD and Holining 1959) and their existence has been confirmed in other laboratories, for example HARRIS (1962) found persistent negative arteriovenous differences when fasting subjects exercised. The negative values recorded in this study are, however, not tissue, but calculated cell exchanges and so cannot really be explained as simple shifts of glucose into and out of the tissues (extracellular space). There is the possibility, raised by earlier work and acknowledged by HARRIs, that there may be an enzyme or enzymes of adaptation in muscles (for example a glucose-6-phosphatase). In such cases as our four juvenile diabetics it can be postulated that secondary metabolic effects from, say, glucose starvation of the C.N.S. in insulin hypoglycaemia or diabetic pre-coma acts as a stimulus for the synthesis of such enzymes in tissues other than the liver.

The alternative explanation is that with increasing blood glucose levels there are increasing errors in blood glucose estimation. We doubt if error explains but a small part of our findings with respect to cell uptakes by the diabetics, but pending more information about muscle enzymes it cannot be ruled out.

Our main finding is the differences between the groups, and here the level of blood sugar must be taken into consideration in our analysis of the uptake results, which has been done in Figures 1, 2 and 3. These relate cell glucose uptake to venous blood sugar levels (taken as a more accurate index of the glucose concentration in the extracellular fluid than the arterial level). The enclosed areas cover all the points for the cell glucose uptake/venous blood glucose level results obtained at various times during glucose tolerance (Fig. 1) glucose-insulin tolerance (Fig. 2) and insulin sensitivity tests (Fig. 3). The symbols indicate the mean glucose uptake/mean venous glucose level values for each subject. It is apparent that there is very little overlap between the groups: indeed the juvenile diabetics are separated from the other groups in all the tests, with a wide scatter of glucose uptakes and, as mentioned above, a number of negative values. 


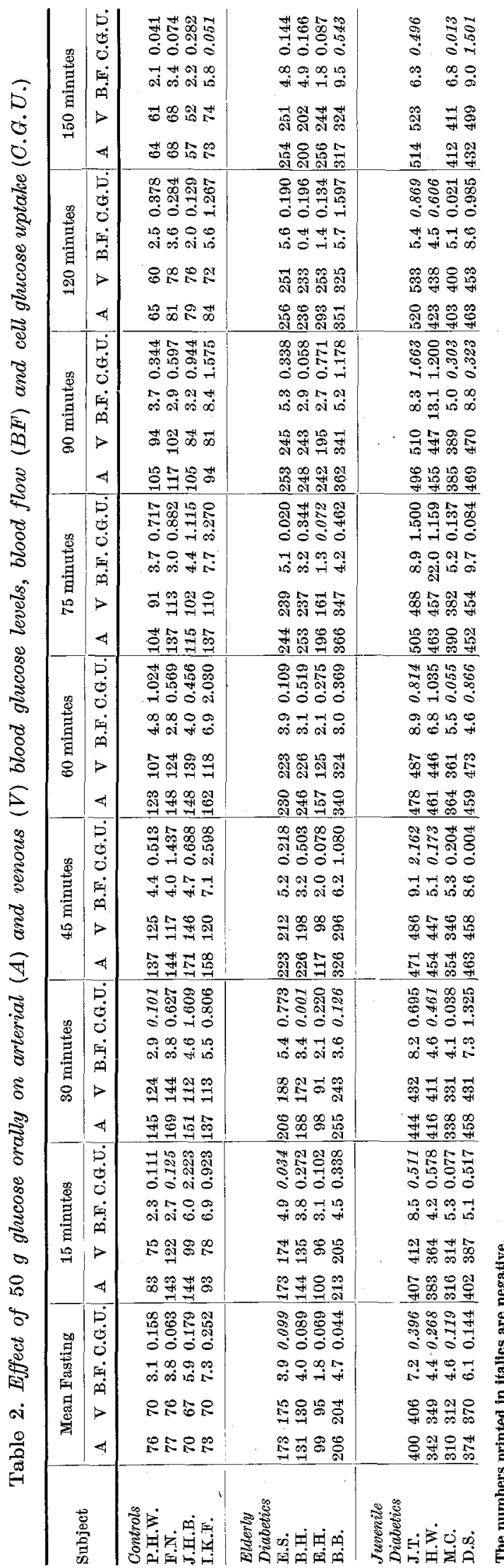

The adult type diabetics are almost completely separated from the controls in the glucose tolerance test, and although the glucose uptake values are remarkably similar to those of the plump controls they are less than those of the lean controls. In the glucose insulin tolerance test, the range of glucose uptake is increased beyond that of the control groups, as is also the case in the insulin sensitivity test, although here the group is completely separated from the others by higher blood sugar levels.

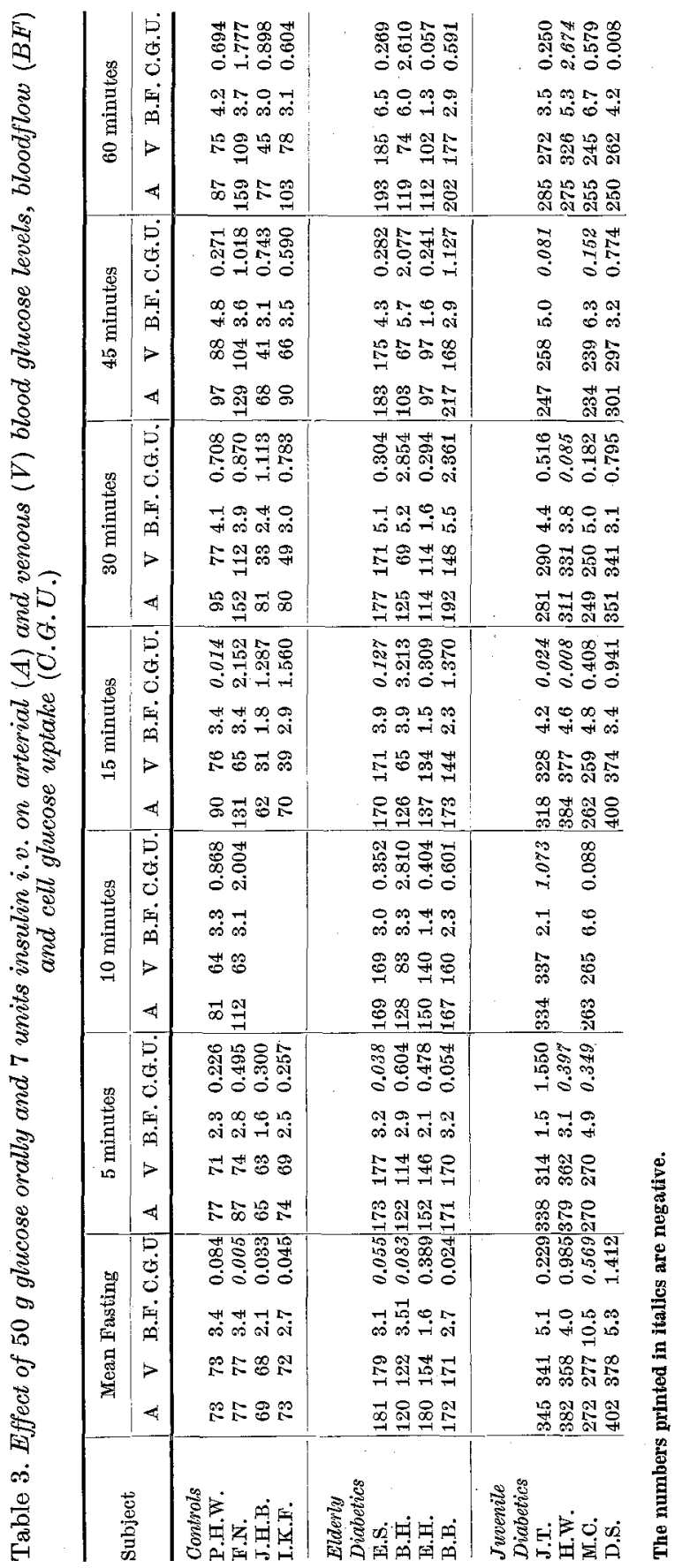


The data from plump and lean controls are almost completely separated from one another in the glucoseinsulin tolerance and insulin sensitivity tests, with the lean controls having the lower blood glucose values. In the glucose tolerance and insulin sensitivity tests glucose uptake extends to higher values in the lean controls, but not in the glucose insulin test.

There is plenty of evidence from in vitro studies that elevation of the glucose level increases cell uptake, but it is apparent from Fig. 1, 2 and 3 that in

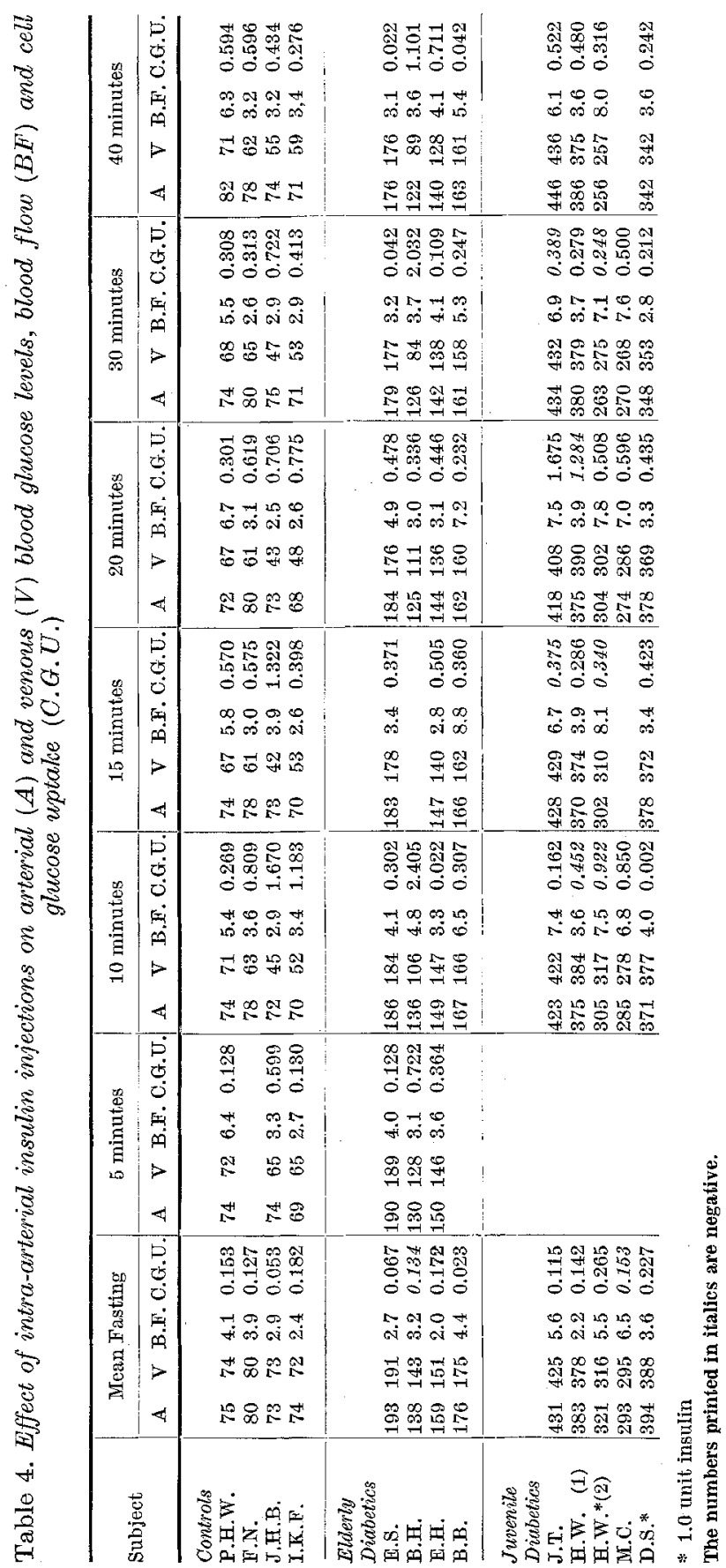

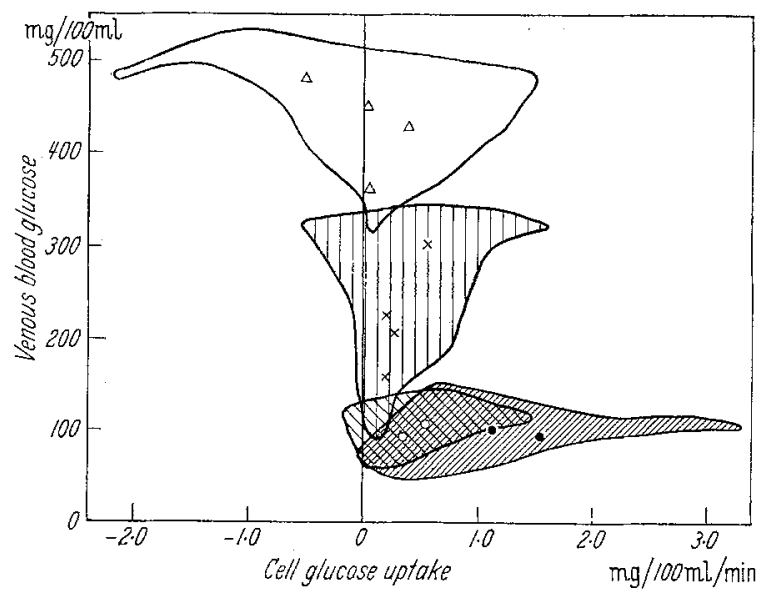

Fig. 1. Glucose Tolerance Test - Relationship between venous blood glucose and cell glucose uptake in controls and diabetics

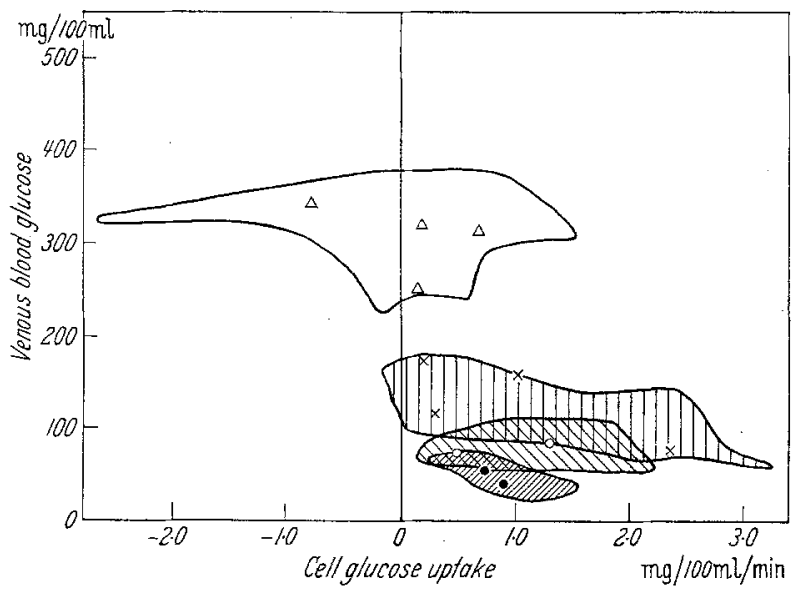

Fig. 2. Glucose-Insulin Tolerance Test - Relationship between venous blood glucose and cell glucose uptake in controls and diabetics

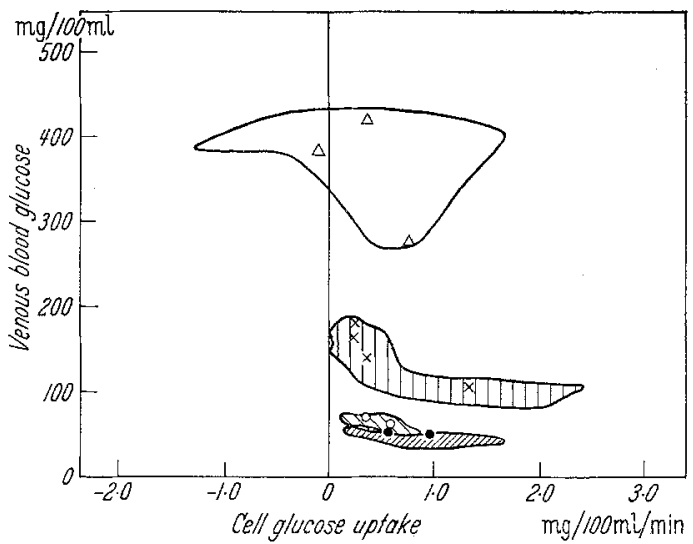

Fig. 3. Insulin Sensitivity Test ( 0.1 unit insulin intra-arterially) - Relationship between venous blood glucose and cell glucose uptake in controls and diabeties

the diabetics (juvenile or elderly) uptake is less than would obtain for the normals at such high levels of glucose. (There is an exception to this in the case of one adult type diabetic in the tests involving insulin.) 
Bearing in mind how the height of the blood sugar segregates the groups in terms of uptake, we shall proceed to comparisons in terms of mean cell glucose uptake in the various groups.

Glucose Tolerance Test. Comparisons have been made between the control subjects as a whole, controls, lean and plump separately, and elderly and juvenile diabetics.

It will be seen (Fig. 1) that the groups can be ranked in order of mean cell glucose uptake $(\mathrm{mg} / 100$ $\mathrm{ml} / \mathrm{min}$ ) as one moves from the data of lean controls (1.12), to controls as a group (0.85), plump controls $(0.46)$, elderly diabetics $(0.35)$ and juvenile diabetics $(-0.08)$. The difference between the lean and plump controls has been amply confirmed by more recent investigations which demonstrated a statistically significant $(P=0.01)$ linear correlation between fat fold thickness and cell glucose uptake after the oral $50 \mathrm{~g}$ glucose load independent of age (WHicheLOW, BUTTERFIELD and ABRAMS 1964). It is interesting that there was no real difference of cell glucose uptake, although there was between the plump controls and the elderly diabetics whereas the negative and negligible mean uptakes among the juvenile diabetics are different from the findings in all other groups.

Glucose-Insulin Tolerance Test. As can be seen from Fig. 2 glucose uptake by the juvenile diabetics (mean 0.012) tended to be lower than obtained for the controls and elderly diabetics (means 0.81 and 0.96 respectively), despite much higher blood sugar values. There was no real difference between the uptake in lean and plump controls (means 0.81 and 0.82 ) but the rise of blood sugar was greater in the plump subjects (Fig. 2).

Looking for an effect of intravenous insulin (7 units) given with the oral load by comparing the glucose uptake over the first hour of the glucose insulin and glucose tolerance tests shows that the hormone had a significant effect in the elderly diabetics $(P=0.01)$ but not in the other groups, though of course the blood sugar values were lower.

Intra-arterial insulin. The mean increases of glucose uptake over basal conditions following intraarterial insulin (0.1 unit) for control subjects was 0.51 . It was greater in lean $(0.66)$ than plump controls $(0.36)$. Elderly diabetics showed a similar rise $(0.49)$. In contrast, juvenile diabetics showed a negligible increase in mean glucose uptake (0.12), despite very much higher blood sugar values.

Considering these findings overall, it is apparent that, when ranked in order, the peripheral tissues of the lean control subjects are most sensitive to insulin: the higher peripheral glucose uptake after oral glucose was presumably in response to endogenous insulin. Next in rank came the plump control subjects whose peripheral tissues showed responses surprisingly similar to the elderly diabetics who follow them in order. In all tests the glucose uptake by the juvenile diabetics was lowest. Their peripheral tissues were so unres- ponsive to insulin, intravenous or intra-arterial, whether they were lean or plump, that a similar block to endogenous insulin might be a precipitating factor in the disorderly carbohydrate metabolism in these cases (BUTTERFIELD 1962).

In this connexion it is interesting that, as observed in a previous study (BUTTERFIELD and HoLLING 1959) the blood flow in the juvenile diabetics was higher than found in control subjects and elderly adult-onset cases $(P=0.001$ in both cases). The only other trend discovered in these measurements was a tendency for the flow rate to rise at some time during the observations in 24 out of the 36 tests. In one or two cases, conspicuous rises occurred, which we attribute to emotional fluctuations. They do, however, indicate the need to monitor the blood flow in clinical studies using arterio-venous differences.

\section{Commentary}

Glucose Tolerance Test. During the first fifteen minutes after the oral glucose load the arterial glucose level rose in all three groups of subjects (Fig, 4 and Table 2). It reached a peak in the controls at 45 minutes and had returned to the fasting level by two hours. In these subjects during the rising arterial glucose level there was a widening of the arterio-venous difference, and a marked increase in cell glucose uptake

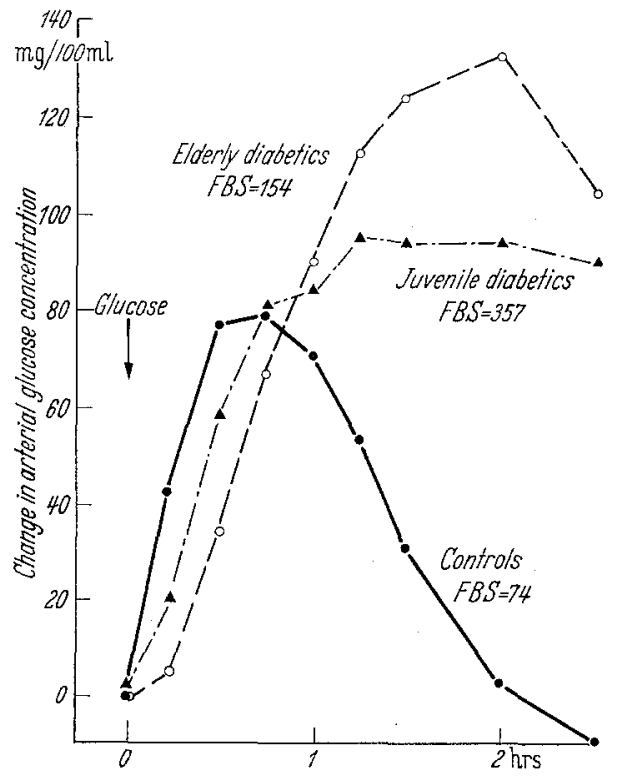

Fig. 4. Changes in arterial glucose concentration after $50 \mathrm{~g}$ glucose orally in control subjects, and adult and juvenile type diabeties

which, like the arterial glucose level, had returned to the fasting value by the end of the test (see Fig. 5 and Table 2). Using different assay techniques YaLOw and Berson (1961) and Antontades, Gundersex, Beigelman, Prue and Bougas (1962) have shown that there is a rapid increase in the endogenous free plasma insulin levels in non-diabetic subjects following the oral administration of glucose, reaching peak levels be- 
tween 40 and 60 minutes. This coincides with the time when of peak arterial glucose levels in our control subjects, and moreover the time of maximum cell glucose uptake is between 30 and 90 minutes.

From the mean cell glucose uptakes (Table 2) it can be calculated that in a standard non-diabetic subject, with a muscle mass of $30 \mathrm{~kg}$ behaving like the tissues of the deep muscle compartment of the forearm, some $31 \mathrm{~g}$ of the $50 \mathrm{~g}$ glucose load. would enter the muscles of the body during the test. However, the two plump subjects, P.H.W. and F.N. showed considerably lower cell glucose uptakes than the thin subjects, J.H. B. and I.K.F. (Table 2). If these two types are separated it can be calculated that about $46 \mathrm{~g}$ of the glucose load - that is almost all of it - would be taken up by the muscle tissues of the thin subjects, whereas only $16 \mathrm{~g}$ - about one third of the load - would be assimilated by the muscles of the plump subjects (see Table 5).

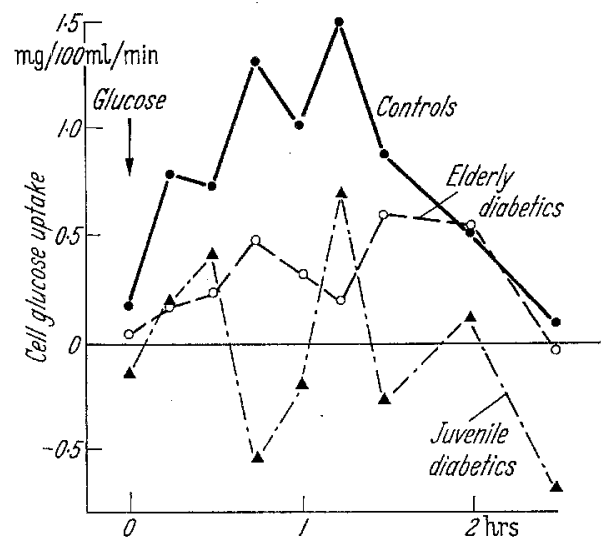

Fig. 5. Effect of $50 \mathrm{~g}$ glucose orally on peripheral cell glucose uptake in control subjects, and adult and juvenile diabetics

Table 5. Comparative glucose uptakes by $30 \mathrm{~kg}$ muscle tissue in different groups of subjects

\begin{tabular}{l|r|r}
\hline \multicolumn{1}{c|}{ Subjects } & $\begin{array}{l}\text { GTT } \\
\text { g/hr. }\end{array}$ & $\begin{array}{c}\text { GITT } \\
\text { g/hr. }\end{array}$ \\
\hline Lean Controls & 22 & 16 \\
Plump Controls & 7 & 16 \\
Elderly Diabetics & 5 & 20 \\
Juvenile Diabetics & 0 & 0
\end{tabular}

The mean arterial glucose level in the elderly diabetic subjects rose much higher after glucose (130 mg/100 ml above the fasting level) than in the controls $(80 \mathrm{mg} / 100 \mathrm{ml}$ above fasting), and the peak level occurred much later - at two hours. The rise of cell glucose uptake was smaller and much slower, maximum values occurring towards the end of the test. These late peak values corresponded with the late appearance of endogenous insulin also reported by ANTONIADES et al. (1962) and YALOW and Berson (1961) in this type of diabetic subject.

Calculations of total glucose uptake by $30 \mathrm{~kg}$ of muscle tissue in these subjects would give a mean value of $12 \mathrm{~g}$ of the glucose load, somewhat similar to that obtaining with the plump control subjects (Table 5).
Unlike the other two groups there was, on average, no glucose uptake by the peripheral muscle cells in these juvenile cases. This finding and the form of the arterial glucose curve suggests that no endogenous insulin was released in response to the hyperglycaemia, which is in harmony with the fact that all four subjects were dependent on large doses of exogenous insulin, and prone to ketosis upon withdrawal.

It is important to enquire why the rise of arterial blood glucose in the juvenile diabetic cases was smaller than that in the elderly diabetic subjects, although in both the mean rate of rise during the first half hour lagged behind the controls (Fig. 4). High but rather flat glucose tolerance curves are not uncommon in severe diabetics and might imply glucose utilization in the peripheral tissues. In the present series, it was not due to a relatively small dose of glucose per $\mathrm{kg}$ body weight since the mean weights in the three groups were similar. It seems probable that the intense glycosuria associated with the hyperglycaemia of the juvenile cases, both fasting and during the test, was partly responsible. In one subject, D.S., who had a rise of blood sugar during the test of $94 \mathrm{mg}$ per $100 \mathrm{ml}$, the renal glucose excretion in the fasting state was $5 \mathrm{~g}$ per hour. Between 0 and 75 minutes after the administration of $50 \mathrm{~g}$ glucose, this rose to $6.5 \mathrm{~g}$ per hour and to $9.5 \mathrm{~g}$ per hour between 75 and 150 minutes, giving an average of $8 \mathrm{~g}$ per hour, or a total of $20 \mathrm{~g}$ over the whole test. In drawing up a balance sheet of body economy during the test, the unknown factor is glucose derived from hepatic gluconeogenesis. If it is assumed that gluconeogenesis ceased when glucose absorption from the gut began, we can account for at least $20 \mathrm{~g}$ of the initial glucose load by urinary losses. Since none of the glucose disposal can be attributed to assimilation by the muscles of these juvenile diabetics, had it not been excreted this $20 \mathrm{~g}$ glucose would have accumulated in the extracellular fluid and caused an additional rise in the blood of $133 \mathrm{mg} / 100 \mathrm{ml}$, giving a total rise of about $227 \mathrm{mg} / 100 \mathrm{ml}$.

The difference between this value and the peak observed gives an indication of the diversity of factors which have to be taken into consideration in trying to interpret oral glucose tolerance results.

Glucose-Insulin Tolerance Test. The arterial glucose levels in the controls rose above the fasting level by approximately $30 \mathrm{mg} / 100 \mathrm{ml}$ during the first hour (Fig. 6) a smaller rise than after glucose alone. However, the cell glucose uptake over the first hour of the test was much the same as that during the first hour of the glucose tolerance test (Fig. 7 and Table 3). Injection of 7 units of insulin, therefore, seemed to have little effect on how much glucose was taken up by the peripheral cells, predominantly muscle fibres, but allowed it to occur at a lower blood sugar level in both plump and lean control subjects.

The concurrent injection of insulin with the glucose drink had a more marked effect on the elderly diabeties. In this group the mean arterial glucose level fell about 
$10 \mathrm{mg} / 100 \mathrm{ml}$ (Fig. 6) in contrast with the conspicuous rise during the glucose tolerance test (Fig. 4), and with this fall the arteriovenous difference widened and the cell glucose uptake increased to the level found in the

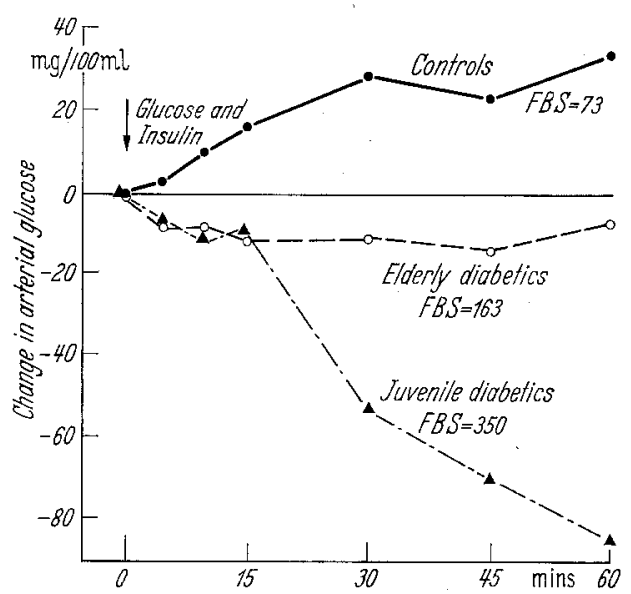

Fig. 6. Effect of glucose ( $50 \mathrm{~g}$ orally) and insulin ( 7 units i.v.) on the arterial glucose concentration in control subjects, and adult and juvenile type diabetics

non-diabetics during both glucose and glucose insulin tolerance tests (Fig. 7 and Table 3). Thus the ability of the peripheral tissues in the elderly diabetics to take up glucose was greatly enhanced by the injection of insulin; they not only took up an increased amount of sugar but did so when the arterial blood sugar level was falling. The effect of insulin upon the arterial glucose level of the juvenile diabetic group was even greater than in the mild diabetic group. After an initial 15 minute rise, there was a marked mean fall of $65 \mathrm{mg} / 100 \mathrm{ml}$ below the fasting level by 60 minutes. Thus endogenous glucose, as well as glucose absorbed from the gut, was disappearing from the blood stream. However the peripheral tissues were not removing this glucose from the extracellular fluid since there was negligible cell glucose uptake during the first hour of the glucose-insulin tolerance test (Fig. 7 and Tables 3 and 5).

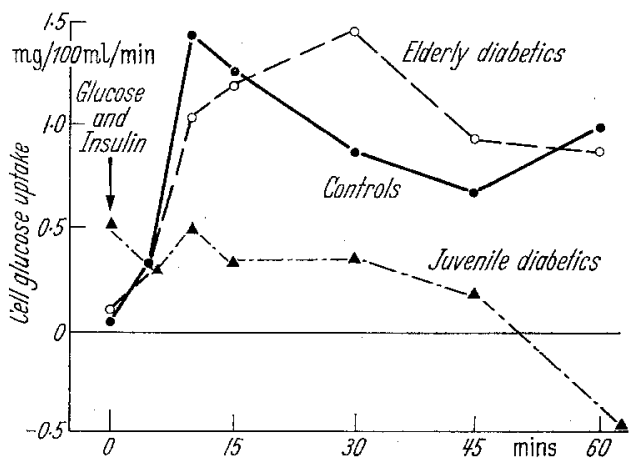

Fig. 7. Effect of glucose ( $50 \mathrm{~g}$ orally) and insulin (7 units i.v.) on peripheral cell glucose uptake in control subjects, and adult and juvenile type diabetics

Intra-arterial Insulin. The insulin resistance of the peripheral tissues of the juvenile-type diabetics was confirmed by injecting the hormone into the brachial artery to perfuse the forearm tissues. All the controls 0,1 unit insulin. This dose had negligible effects on the arterial glucose level, but caused a conspicuous fall of the local venous glucose level and a great increase in the cell glucose uptake (Fig. 8), the peak effect occurring 10 minutes after the insulin injection. The elderly diabetics, with the same insulin dose, showed a similar increase in cell glucose uptake and the peak insulin effect again occurred 10 minutes after the injection. The arterial glucose level fell steadily during the fasting period and continued to fall at the same rate after the insulin injection.

The juvenile-type diabetics, who received 0.1 unit, also showed a progressive fall of the systemic glucose level, both before and after insulin. In this group there was wide variation in the calculated cell glucose uptake values at various times after insulin, but on average less glucose was taken up than in either the elderly diabetics or control subjects (Table 4). Two of the juvenile diabetics received 0.1 unit, a third receiving 1.0 unit, and the fourth was given both doses on separate occasions. Even this larger dose of insulin did not increase the local cell glucose uptake, although the arterial glucose level fell more rapidly than in the

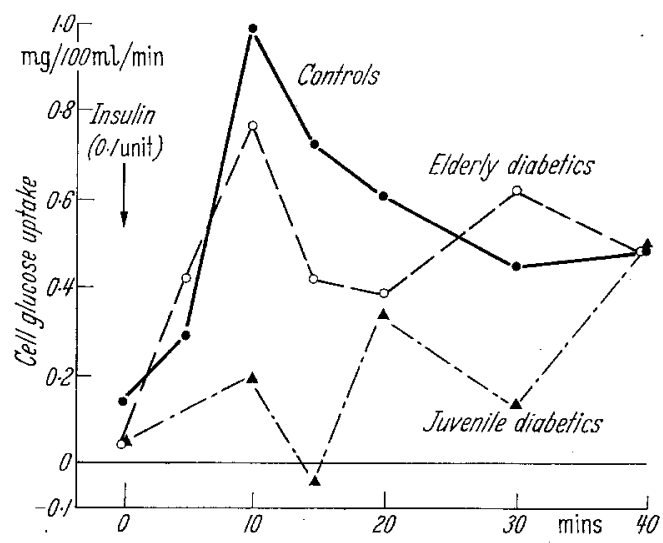

Fig. 8. Effect of intra-arterial insulin (0.1 unit) on peripheral cell glucose uptake in control subjects, and adult and juvenile diabetics

preliminary resting period (Table 4 ). We have shown in other work (ButTerfield, Garratt and WHichELOw 1963) that diabetics have an impaired ability to clear intramarterially injected insulin from the blood stream into their forearm tissues, and as a consequence show a reduced glucose response. Therefore, it would seem that the juvenile diabetics studied here also had a marked impairment of insulin fixation which would account for the small effect on glucose metabolism in the forearm.

\section{Discussion}

There seems to be a remarkable similarity between the peripheral glucose uptake in plump control subjects and adult-onset diabetics.

The elderly diabetics studied here clearly have endogenous insulin responses to hyperglycaemia to 
cause the peripheral glucose uptake which is comparable to that seen in the plump controls. Why is their blood sugar so much higher? Either they need the higher level to induce adequate insulin release from the $\beta$-cells, or some other tissue, which is important in glucose disposal in plump non-diabetic subjects, is no longer taking up sugar. The main clue is that plump control subjects can have very flat glucose tolerance tests, comparable to the excellent glucose tolerance observed after high calorie feeding by HтмsworTH (1935) and seen in our subject P.H.W. It is therefore suggested that the difference between adult onset diabotics and plump non-diabetics is that, in the former, impaired insulin release and the response of the splanchnic tissues allows abnormally large amounts of glucose to escape through the liver into the general circulation. This defect can be remedied if there is an abrupt rise of circulating insulin, as obtained when insulin was injected intravenously in the glucoseinsulin tolerance test.

There is an even stronger case for invoking similar but more pronounced abnormalities in the carbohydrate metabolism of the splanchnic tissues and liver to explain the responses observed in juvenile diabetics.

During the glucose-insulin tolerance test, the injected insulin caused a rapid fall of the arterial glucose concentration. Although without effect on the peripheral tissues, it had a marked effect on some other organ or tissues, causing the uptake there of a considerable amount of glucose. Whatever organ or tissue this may have been, it was remarkably sensitive to injected insulin in these diabetics with high blood sugars and also sensitive, but to a lesser degree, in the elderly diabetics. Indeed there seems to be a gradual trend across the subjects we studied, for we find a significant correlation between the fasting arterial glucose level and the mean change of blood sugar observed over the hour following intravenous insulin in the glucoseinsulin test. The relationship between these two parameters, shown in Fig. 9a is unlikely to be due to chance $(R=0.683, P=0.01)$. A similar correlation exists between the fasting arterial glucose value and the change at $30 \mathrm{~min}$ and $60 \mathrm{mins}$ (Fig. $9 \mathrm{~b}$ and $\mathrm{c}$ ).

From Fig. 9 it appears that when the fasting blood sugar is above $155 \mathrm{mg} / 100 \mathrm{ml}$ some organ or tissue becomes so exquisitely sensitive to insulin that although very little sugar is removed by the peripheral tissues, absorption of glucose from the gut cannot keep pace with its demands for glucose and the systemic glucose level falls. In the control subjects with fasting blood sugar levels below $155 \mathrm{mg} / 100 \mathrm{ml}$ the insulin sensitivity of this organ or tissue was not so marked. Nevertheless, it was still apparent since the degree of hyperglycaemia after glucose and insulin was less than that after glucose alone, although the uptake of glucose by the peripheral tissues was unaltered.

Conclusive deductions cannot, of course, be made about this insulin sensitive site from measurements carried out solely in the periphery, but we can weigh the available evidence. The main possibilities seem to be adipose tissue, the splanchnic area and the liver. It seems very unlikely that the first could account for the findings. Bearing in mind the rapid rate of removal of glucose from the circulation necessary to cause the falls of systemic glucose levels we have observed, and the relatively low blood flow to peripheral adipose tissue, the glucose extraction would have to be very high and the venous glucose content, consequently, very low. Calculations indicate that it would have to approach zero. Such values have never been recorded in our cases when blood samples have been deliberately taken from veins draining predominantly adipose tissue. Furthermore, there may well be some adipose tissue draining into the catheter in the deep vein used in our observations, but we detected no glucose uptake in the juvenile cases where the effect we are attempting to explain would be most conspicuous.
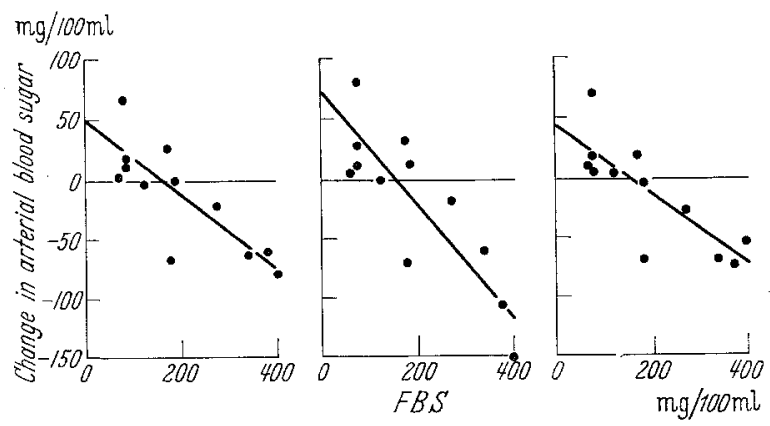

Fig. 9 a) b) and c). Relationship between fasting arterial blood glucose level and change in arterial glucose concentration after $50 \mathrm{~g}$ glucose orally and 7 units insulin I.V. a) mean change, b) change at 30 mins and $c$ ) change at 60 mins

On the other hand, it would appear that the findings could all be reconciled with current opinion if it is assumed that the splanchnic area and the liver were mainly concerned. The concept that glucose rapidly enters the liver during the glucose-insulin tolerance test in subjects with high blood sugars is also supported by separate studies where the same doses of insulin and glucose were given, and blood pyruvate levels kindly measured by Dr. KELSEY FRY, in samples taken as before from the brachial artery and antecubital vein and an hepatic vein through a catheter introduced under fluoroscopy.

In normal subjects the levels of pyruvate never exceeded $1.2 \mathrm{mg} / 100 \mathrm{~g}$ blood anywhere, at any time during the glucose-insulin test. By contrast, in one juvenile diabetic (D.S.) very high pyruvate levels were detected in the hepatic vein, rather lower ones in the artery and lower still in the deep forearm vein, as shown in Table 6. In two other juvenile diabetics (H.W. and J.T.) we found similar overall high levels but less clear-cut differences between the hepatic vein and arterial levels. Nevertheless we interpret these findings as evidence that very high systemic and hepatic vein pyruvate levels during glucose-insulin tolerance tests reflect the conversion of large amounts 
of glucose to pyruvate by the liver or the failure of that organ to accept pyruvate released earlier from the splanchnic area. It is also manifest from the large positive differences between arterial and deep vein levels that some pyruvate was taken up by the peripheral tissues of brittle juvenile diabetics who did not take up glucose there.

Table 6. Blood pyruvate levels in brachial artery, antecubital vein and hepatic vein in a severe juvenile diabetic, after $50 \mathrm{~g}$ glucose orally and 7 units insulin i. $v$.

\begin{tabular}{c|c|c|c}
\hline \multirow{2}{*}{ Minutes } & \multicolumn{3}{|c}{$\begin{array}{c}\text { Blood Pyruvate Levels } \\
\mathrm{mg} / 100 \mathrm{~g} \text { blood }\end{array}$} \\
\cline { 2 - 4 } & $\begin{array}{c}\text { Hepatic } \\
\text { vein }\end{array}$ & Artery & $\begin{array}{c}\text { Anteeubital } \\
\text { vein }\end{array}$ \\
\hline 0 & 0.2 & 0.6 & 0.4 \\
10 & 0.5 & 0.7 & 0.5 \\
20 & 1.2 & 1.0 & 0.8 \\
30 & 3.2 & 2.4 & 1.1 \\
45 & 4.0 & 3.0 & 1.5 \\
60 & 4.7 & 2.9 & 1.7
\end{tabular}

We have reported elsewhere (KELSEY FRY and BUTTERFIELD 1962) that large rises of pyruvate may occur in the venous blood in other brittle diabetics during glucose-insulin tolerance tests, but not when glucose was given alone. The abnormality of pyruvate metabolism would have been more clear-cut in those studies if we had followed arterial rather than venous levels of pyruvate. However, it is apparent that the second metabolic block we postulated in diabetes at the level of pyruvate utilisation, is probably really a reflection of metabolic events involving glucose entrance into hepatic or splanchnic cells under the influence of insulin when the blood sugar was high.

We have shown elsewhere (ButTERFIELD, GarRatT and WHrcherow 1963) that the peripheral tissues of diabetics are less sensitive to insulin than those of controls, due to an impairment of insulin clearance from the circulation. The present findings indicate that this is not true for the liver; there is a tendency for its insulin response to increase with increasing elevation of the fasting blood sugar, as seen in the most severe diabetics. In these latter juvenile diabetics, with large urinary sugar losses in the fasting state, the Jiver must have been actively involved in gluconeogenesis.

Why should the gluconeogenetic liver be so sensitive to insulin? Various possibilities have come to mind. The injected insulin may be bound to plasma proteins and rapidly taken up by the iver but not the peripheral tissues. We know that such cases may show protein binding of radio-iodine labelled insulin, studied by electrophoresis (CAMERON 1962). There are, however, certain points against this suggestion; the elderly diabetics and controls, who had not been treated with insulin and would not have antibodies to beef insulin, follow the same trend in the phenomemon under discussion, shown in Fig. 9a-co. There would therefore seem to be other factors operating which influence the distribution and sites of action of insulin, and en- quiries along these lines are under way (ButTeRFIELD 1964) (KaLdor, RIHAN, Nichols and ButTERfield 1964).

While there is obviously uncertainty about the nature of such factors underlying the present findings, there is no doubt that the dissection of diabetes in terms of tissue glucose disposal rather than simply as systemic sugar levels, will yield much important new information about this disease. Thus, the vexed question of the sensitivity of the liver to insulin, which was accepted by Soskrn and LeviNe (1952), then rejected by Levine and Fritz (1956), and now being reaccepted as the result of the work of MADISON, Combes, Adams and Strickland (1960) may be resolved for man. Our results indicate that it depends upon the circumstances of the body's overall glucose economy, varying from one occasion to another. Again, the separate study of the peripheral tissues suggests that, under some circumstances, the Cori cycle may not hold in our diabetic patients whose muscles apparently took up pyruvate but not glucose.

From a therapeutic point of view, the most important point arising from the foregoing is the implication that different organs can have different insulin sensitivities under different circumstances. With increasing hyperglycaemia after the withdrawal of insulin or oral antidiabetic therapy the liver seems to be increasingly insulin sensitive. A considerable portion of a glucose load can be disposed of by that organ in hyperglycaemic circumstances. Perhaps so-called unstable juvenile diabetics suffer hypoglycaemic attacks because we are wrong to assume that the higher their fasting blood sugar the larger the morning dose of insulin required.

\section{Acknowledgments}

We are indebted to Mrs. Annetre May for technical assistance. One of us, M. J. W. was supported by grants from the Medical Research Council and the Endowments Fund of the Governors of Guy's Hospital.

References. Antoniadis, H. N., K. Gundersen, P. M. Beigerman, H. M. Pyle and J. A. Bougas: Studies on the state, transport and regulation of insulin in human blood. Diabetes, 11, 261 (1962). - BUTTERFIELD, W. J. H. : Disorders of Carbohydrate Metabolism. Pitman Medical, London. p. 91. (1962). - Summary of results of the Bedford Diabetes Survey. Proc. roy. Soc. Med., 57, 196 (1964) ; - Journees Annuelles de Diabetologie de l'HôtelDieu. Editions Médicales Flammarion, Paris. p. 139 (1964). - Butterfieldo, W. J. H., C. J. GarratT and M. J. WHICHELOW: Peripheral hormone action: studies on the clearance and effect of $\left[\mathrm{I}^{131}\right]$ iodo-insulin in the peripheral tissues of normal, acromegalic and diabetic subjects. Clin. Sci., 24, 331 (1963). - BuTTERfIEId, W. J. H., and H. E. Holling: Peripheral glucose metabolism in fasting control subjects and diabetic patients. Clin. Sci. 18, 147 (1959), - BUTterfietD, W. J. H., and M. J. Whichelow: Are thyroid hormones diabetogenic? A study of peripheral glucose metabolism during glucose infusions in normal subjects and hyperthyroid patients before and after treatment. Metabolism, 13, 260 (1964). CAMreron, J. S. : The stability of $\mathbf{I}^{131}$ insulin in solution and 
its use in studies of the forearm uptake of insulin in man. Guy's Hosp. Rep. 111, 190 (1962). - Harris, P., M. Batemar and J. Gloster: The metabolism of glucose during exereise in patients with rheumatic heart disease. Clin. Sci. 23, 561 (1962). - HimsworTH, H. P.: The dietetic factor determining the glucose tolerance and sensitivity to insulin of healthy men. Clin. Sci. 2, 67 (1935). - Hrmsworth, H. P., and R. B. KerR: Insulin sensitive and insulin-insensitive types of diabetes mellitus. Clin. Sci., 4, 119 (1939). - HUGGETT, A. St. G., and D. A. NIXon: Use of glucose oxidase, peroxidase and o-dianisidine in the determination of blood and urinary glucose. Lancet 121, 368 (1957). - JAcobsen, Aa. Th. B.: The Blood Sugar in Normal Persons and Diabetic Patients. (in Danish). Gyldendal, Copenhagen (1917). - KaLDor, A., Z. Ex BAZ, RiHAN T. R. Nichols and W.J. H. BUTTERFIELD : Effects of adenine and guanine on hepatic glucose release and on the action of insulin on the liver. Nature, 203, 1186 (1964). - KELSEY FRY, I., and W. J.H. BUTTERFIELD : Carbohydrate metabolism in diabetics: a possible intracellular block. Lancet 121, 66 (1962). - LEviNE, R., and I. B. Fritz: The relation of insulin to liver metabolism. Diabetes, 5, 209 (1956). - LUNDBAEK, $\mathrm{K}$. Intravenous glucose tolerance as a tool in definition and diagnosis of diabetes mellitus. Brit. med. J., 1, 1507 (1962). - Madison, L. L., B. Combes, R. Adalis and W. STRICKLAND: The physiological significance of the secretion of endogenous insulin into the portal circulation. Evidence for a direct immediate effect of insulin on the balance of glucose across the liver. J. clin. Invest., 39, 507 (1960). - MCARdLe, B. M.: The quantitative estimation of pyruvic and $\alpha$-oxoglutaric acids by paper chromatography in blood, urine and cerebrospinal fluid. Biochem. J., 66, 144 (1957). - SoskIN, S., and R. LeVINE: Carbohydrate Metabolism. University of Chicago Press, Chicago. p. 206 (1952). - YALow, R. S., and S. A. BERSON: Immunoassay of plasma insulin in man. Diabetes, 10, 339 (1961). - ZIERLER, K. L.: Theory of the use of arterio-venous concentration differences for measuring metabolism in steady and non-steady states. J. clin. Invest., 40,2111 (1961).

W. J. H. ButTERFIELD

Department of Medicine Guy's Hospital Medical School London, S.E. 1

England 